\title{
On the notion of home and the goals of palliative care
}

\author{
Wim Dekkers
}

Published online: 27 November 2009

(C) The Author(s) 2009. This article is published with open access at Springerlink.com

\begin{abstract}
The notion of home is well known from our everyday experience, and plays a crucial role in all kinds of narratives about human life, but is hardly ever systematically dealt with in the philosophy of medicine and health care. This paper is based upon the intuitively positive connotation of the term "home." By metaphorically describing the goal of palliative care as "the patient's coming home," it wants to contribute to a medical humanities approach of medicine. It is argued that this metaphor can enrich our understanding of the goals of palliative care and its proper objectives. Four interpretations of "home" and "coming home" are explored: (1) one's own house or homelike environment, (2) one's own body, (3) the psychosocial environment, and (4) the spiritual dimension, in particular, the origin of human existence. Thinking in terms of coming home implies a normative point of view. It represents central human values and refers not only to the medical-technical and care aspects of health care, but also to the moral context.
\end{abstract}

Keywords Home $\cdot$ House $\cdot$ Metaphor Palliative care $\cdot$ Phenomenology

\section{Introduction}

About ten years ago, a colleague died. On his mourning card was written, "John is at home." I knew that my colleague wanted to die at home, but I still remember my thinking about what the phrase "is at home" could mean. His dead body was laid

\footnotetext{
W. Dekkers

Centre for Ethics, Radboud University Nijmegen, Nijmegen, The Netherlands

W. Dekkers $(\bowtie)$

Scientific Institute for Quality of Healthcare, Section of Ethics, Philosophy and History of Medicine, Radboud University Nijmegen Medical Centre, P.O. Box 9101, 6500 HB Nijmegen,

The Netherlands

e-mail: w.dekkers@iq.umcn.nl
} 
down on a bier in his own house where one could take leave. But because he was a religious person, the interpretation that he had gone back to the Creator was also adequate. Another mourning card read in the same vein: "William, our golden child, our gift from God, has returned to the ancient land where the source of life is."

Around the same time, there was often a commercial on Dutch TV in which all kinds of travelers were shown the way home. Traveling by airplane, train, bus, car, bicycle or walking, they just had to follow the signs to find their home. The weather was cold, windy, and rainy. What they found at home was a cup of soup or coffee (the brand of which I cannot remember). What I do remember, however, is the suggestion that it is a good thing to be at home.

It is through these kinds of experiences that I came to think about the relationship between the notion of home and the goals of palliative care. "Home" has an intuitively positive connotation. Like "peace," "happiness," and "health," words such as "home" and "going home" evoke positive feelings. Home is someone's own place, the place to be. Home is a place of confidence, where one can trust the other, where one feels comfortable, safe, and where one's privacy is most respected.

The term "home" plays an important role in all kinds of narratives about human life. All sorts of disciplines have contributed to our understanding of home: geography, architecture, sociology, psychology, psychoanalysis, anthropology, history, and philosophy. Especially in literary works, one can find metaphors used to describe experiences of being home. "Home sweet home" and "there is no place like home" are common messages found in many poems, novels, songs and movies. ${ }^{1}$ According to the French philosopher Gaston Bachelard, the reading of poetry is essential to grasp the specific human values of the material world around us. In his view, "poetic creation" and "poetic power" are needed in order to obtain that insight. That is why his influential book The Poetics of Space contains many quotations from Rilke, Baudelaire, George Sand, Rimbaud, Paul Valéry and many other poets and novelists [2].

The notion of home is very broad and transcends the borders of medicine and health care. Although there are good reasons to regard palliative care as an integral part of medicine and health care, ${ }^{2}$ I will focus on the goals of palliative care and ignore the differences and similarities between palliative care and the rest of health care. By exploring four interpretations of the metaphor "coming home," I want to contribute to our understanding of the goals of palliative care and its proper objectives. The next section is a brief exploration of the relationship between home and metaphor. The subsequent section is a short introduction to a phenomenology of home. Thereafter, a four-fold interpretation of "being or coming home" related to palliative care will be presented. Finally, some theoretical and practical potentials and limitations of the metaphor "coming home" will be discussed.

\footnotetext{
${ }^{1}$ See, for example, Doris Lessing's novel Going Home, which is an account of a journey back to Zimbabwe in Africa, the country where she grew up and with which she remained involved [1].

2 Because, for example, the relief of suffering is considered their common fundamental goal [3, 4].
} 


\section{Home and metaphor}

"Is there any experience more familiar to us than the experience of our home: the experience of being at home, being away from home, or being on our way home? And do we not have a wide knowledge of homes: of good homes, bad homes and even broken homes. Probably we do, but how often do we stop to really reflect on what it is that makes a particular place or house a home?" These are the first lines of a paper, "The Nature of At-Homeness," written by Stefan Baldursson [5]. ${ }^{3}$ When one starts to reflect on the experience of being home, it appears that "home" is difficult to define because of its many layers of meaning: as a physical structure and territory, and as a social and cultural unit [6]. "Home" refers to where one comes from-one's place of birth or home country - the place where one actually lives, or where one is going to.

\section{Metaphor}

If there is one thing that we can learn from a quick scan of the use of the notion of home, it is that it is often used in a metaphorical sense [7]. Aristotle defines metaphor in the Poetics as "the application to a thing of a name that belongs to something else, the transference taking place from genus to species, from species to species, or proportionally." The essence of a metaphor is "understanding and experiencing one kind of thing in terms and concepts of another" [8, p. 5]. Metaphors form an excellent tool to provide a partial understanding of a difficult and complex phenomenon [9]. By using a metaphor we make a familiar thing look different and realize that two seemingly unrelated experiences have something in common. Metaphors may help us to construct a conceptual image of matters, affairs, and situations that are difficult to describe in a more exact, rational way. Metaphors are pervasive, not only in everyday language and thought, but also in action and everyday activities. We find ourselves using metaphors because they already mean something to us and to those around us. They are evolving forms of meaning that are already part of our daily experience.

"Home" is an excellent example of this intrinsic relationship between language and everyday experience. On the one hand, "home" is often used in a metaphorical way in order to express experiences that are difficult to express in other words. On the other hand, in descriptions of experiences of "home," people tend to use metaphors originally stemming from another context.

In literary works one can find metaphors describing experiences of being home, especially in relation to the intertwining of issues such as environment, memory, self, and identity [10]. A metaphor which is frequently used to explain how the environment supports identity is that of an "easy motion through a landscape" [10, p. 211]. A person who is at home "can move fluidly through the dwelling because body-subject knows that space intimately" [Seamon, citation in 10].

\footnotetext{
3 This paper is part of a research project on the notion of home under the leadership of Max van Manen of the University of Alberta (Edmonton, Canada), who is also founder of the web-based project Phenomenology Online.
} 
The self becomes a self that is embodied in the home. Yet intimately entwined with this habitual engagement with the spaces of the home is an apprehension of "boundarylessness" or blending with it. Therefore, amalgamation with one's environment is another main metaphor especially employed in studies of the home life of the elderly. The bodily awareness of the home's spatial dynamics results in a loss of boundary between self and environment and in a bodily identification with the environment. In her novel Union Street, Pat Barker portrays the last few days spent by Alice Bell in the home she can no longer manage. Despite the extreme discomfort of her life, Alice takes pleasure in her sense of amalgamation with her home: "Still she loved the house. Over the years it had become a refuge. Finally, almost an extension of her own body" [10, p. 212].

No metaphor can ever be comprehended independently of its experiential basis. Metaphors are rooted in daily experience. Bachelard, however, insists upon a radical difference between metaphor and image. He acknowledges that a metaphor might give concrete substance to an experience that is difficult to put in other words and that this experience is related to another thing from which it differs. He argues, however, a metaphor is completely different from an image, which is called by him "the pure product of absolute imagination" [2, p. 75]. An image owes its entire being to the imagination. According to Bachelard, a metaphor cannot be studied phenomenologically. ${ }^{4}$ At the most it is a "fabricated image" [2, p. 75] or "an accident of expression" [2, p. 77]. He goes onto say, "A metaphor is a false image, since it does not possess the direct virtue of an image formed in spoken revery" [2, p. 77].

In this paper, I will not further pursue the difference between metaphor and image. I will juxtapose the goal of palliative care and being or coming home, so that the goal of palliative care is described as though it is actually a being or coming home of the patient. ${ }^{5}$

\section{Level of interpretation}

Talking about home is complex because of various levels of interpretation. "Being at home" in the sense I am interested in is something different from the more concrete "staying at home." And most of us would say that "being in the world" is a more fundamental notion than "being at home." But all these distinctions depend upon the level of philosophical consideration and the terminology used.

\footnotetext{
${ }^{4}$ Bachelard calls himself a phenomenologist, but his phenomenology is totally different from Husserl's pure phenomenology with which Bachelard did not want to be associated. Bachelard's phenomenology is "materialistic" in nature. While many phenomenologists (Merleau-Ponty, Sartre) focus on the human body, Bachelard's main interest is in the material aspects of the world, the direct surroundings of a human being: houses, huts, rooms, attics, cellars, corners, drawers, chests, locks, and wardrobes.

5 There is much debate about the differences and similarities between metaphor and simile, but there is also a widely held consensus that a metaphor ("an $\mathrm{x}$ is a y") and a simile ("an $\mathrm{x}$ is like a y") express the same figurative meaning [11]. For the purposes of this paper, I assume that both the expressions "The goal of palliative care is the patient's coming home" and "The goal of palliative care is like the patient's coming home" have the same meaning.
} 
Heidegger is a fine example of a philosopher who uses the word home in order to describe one of the most fundamental aspects of human existence. As Svenaeus explains, in Heidegger's thinking the notions of "homelikeness" ("heimischkeit") and "unhomelikeness" ("unheimlichkeit") play a crucial role [12-14]. It is in the context of an existential analysis of anxiety that Heidegger speaks about unhomelikeness: "In anxiety we feel unhomelike [...] Unhomelikeness means at the same time not being at home" [15, p. 188]. According to Heidegger, unhomelikeness is, even in our everyday modes of being-in-the-world, a basic aspect of our existence, but in our everyday life it is hidden by the dominant beingat-home in the world. Consequently, the being-at-home of the human being is also a being not quite at home in this world: this is my world but it is also not entirely mine. Therefore, health is to be understood as a being-at-home that keeps the fundamental homelessness of human existence-the not being at home in the world - from becoming apparent. Svenaeus considers being healthy and being ill as ways of "being-in-the world." Based upon Heidegger he describes health as "homelike being-in-the-world" and illness as "being-unhomelike-in-the-world."

For Svenaeus, the inherent goal of medicine is the health of the patient rather than the relief of human suffering. Based upon the notion of health as "homelikebeing-in-the-world," he argues that clinical medicine should also encompass "the art of providing of a way home for the patient" [14, p. 104]. This is exactly what I want to develop further. The difference between Svenaeus's approach and mine, however, is that his analysis refers to a fundamental, existential level. I will proceed along a more concrete line of reasoning. This paper is rather a phenomenological analysis in the Merleau-Pontian sense, taking seriously our everyday experience and subjectively lived body, than it is an existential analysis à la Heidegger.

\section{Toward a phenomenology of home}

There is a rich tradition of phenomenologically oriented philosophers who have given "home" a central place in their writings [2, 16-18]. Also scientists of all sorts have shown their interest in the phenomenon of home [19]. What follows is a brief overview of a number of crucial elements which are mentioned in the literature and which are relevant to palliative care.

\section{House and home}

Home is located in space, although it is not necessarily a fixed space. It does not need bricks and mortar. It can be a wagon, a caravan, a boat, a tent or even less than all this. On the bus of Johnny Cash, called "J.C. Unit One," in front of the Rock and Roll Hall of Fame in Cleveland (Ohio) it reads, "I have a home that takes me anywhere I need to go, that cradles me and comforts me [...] my bus of course." Although "home" and "house" have often been used interchangeably, it makes sense to make a clear distinction between the two concepts. The notion of home emphasizes much more than the notion of house its psychological significance to individuals and its cultural, normative, and moral meaning. "Home" is therefore a 
more elusive notion than "house." A house is a "spatial unit in the built environment" or "just a shelter." A home is "the most cherished place for many people" or just "an experience" [7, 20]. Home stands for some mode of being we do not usually experience in other places.

Gaston Bachelard writes, "A house is first and foremost a geometrical object, one which we are tempted to analyze rationally. Its prime reality is visible and tangible, made of well hewn solids and well fitted framework. [...]. But transposition to the human plane takes place immediately whenever a house is considered as space for cheer and intimacy, space that is supposed to condense and defend intimacy" [2, p. 48]. He also writes, "All really inhabited space bears the essence of the notion of home" [2, p. 5]. Although Bachelard seems to blur somehow the distinction between house and home, he also emphasizes that being home is not just living in a house: "A house that has been experienced is not an inert box. Inhabited space transcends geometrical space" [2, p. 47].

\section{Time}

Home is not only located in space, it is also temporally structured [21]. Home refers to the past and is often associated with one's source of origin, one's place of birth or one's house experienced as a child. "Home is where one starts from," T.S. Eliot wrote [22, p. 129, as quoted in 23]. From this perspective, coming home is a journey back to one's roots. Common to the hidden myths of many peoples is the idea that one needs to go away in order to learn, to see new things and to meet new people. But finally, one has to return home, to one's roots, one's home country, parents, or family. Home also refers to the future, to the fact that a human being must follow his or her path of life and find the final destination of his or her existence. It is this temporal structure that is characteristic of home compared with a temporary shelter.

\section{Dwelling and travelling}

According to Bollnow, a human being, called by him "a fugitive on earth" [24, p. 33], gains a stay by rooting himself tight to the ground with the solid walls of his house. Dwelling somewhere is fundamental for human beings. To dwell is not an activity like any other activity, but a determination of human beings in which they realize their true existence. As Bollnow writes, "man needs a firm dwelling place if he is not to be dragged along helplessly by the stream of time" [24, p. 33]. Dwelling somewhere is one side of the coin, travelling the other. The temporal aspect of home is related to the idea of human existence as a journey through life. A well-known saying is "you have to leave home to find your home." It seems as if there can be another home than just the place where one is actually living.

\section{Others}

For most people, the experience of feeling at home is closely related to the experience of others. But the simple observation that people live alone and still have their home clearly shows that the presence of others is not a necessary condition for 
the experience of being at home [5]. Although people who live alone do not have someone waiting at home, they have something waiting. Home is their place with their chairs, tables, books, pictures, and so on. Home can be the place where one can be alone, where one does not have to talk or to listen to others. The question, therefore, is not so much whether someone shares or does not share the home with others, but rather what kind of relationship one has with others at home.

\section{Young and old}

Young and elderly people experience home in a different way. When children are asked where their home is, they mention the house where they are born or where they live. As we grow older and venture into the wider world, the sense of home seems to broaden [25]. Elderly people tend to lean more heavily on their home environment than younger ones. The literature suggests that elderly people generally report a higher level of satisfaction with their current homes than younger ones, although their residential situation might be far from desirable or adequate. Elderly people are generally reluctant to move to a new environment. At the same time they are often forced to do so. For them, a home plays a critical role in maintaining a sense of personal identity and independence, sustaining a meaningful existence, and resisting institutionalization [26].

Ruth, one of the main characters in Marilynne Robinson's novel Housekeeping who is forced to leave her house where she has lived for many years, says: "I [...] could not leave that house, which was stashed like a brain, a reliquary, like a brain, its relics to be pawed and sorted" [quotation in 10, p. 209]. This quotation illustrates that for elderly people, there is much value of remaining in their home because of the comfort and support familiar surroundings and objects provide. Ruth burns her family home when she is forced to leave it. To understand the determination of the elderly to remain at home as long as possible, one must recognize the importance of materiality to home-based metaphors of identity [10].

\section{Home as the goal of palliative care}

The idea I want to put forward is that the goal of palliative care should be "to bring the patient home." The assumption here is that it is an integral part of the medical ethos not only to attend to the health and well-being of patients, but also to assist them in dying and to ensure a humane and dignified death. The four interpretations of "home" and "coming home" that will be analyzed are: (1) one's own house or homelike environment, (2) one's own body, (3) the psychosocial environment, and (4) the spiritual dimension, in particular, the origin of human existence. ${ }^{6}$ The first

\footnotetext{
6 This scheme is based upon a distinction commonly made between the somatic, psychological, social and spiritual dimensions of palliative care and is necessarily abstract. The various interpretations of "home" overlap. Home as a fixed place of abode is also a home in a social way, the place where one can be together with family and friends (or, conversely alone) and where one feels comfortable. This broad interpretation of "home" is, for example, clearly reflected in Mahatma Gandhi's thoughts about "home." The ashram founded by him in 1915 was based upon the idea of "Satyagraha." Life in the ashram should
} 
interpretation refers to the place where one lives and dies, the second to one's bodily well-being, the third to one's psychological well-being, and the fourth to the process of dying. The first interpretation is not necessarily a metaphor, but the other three certainly are.

\section{(1) One's own house}

"Coming home" can be taken literally in the sense of returning to one's own house. This interpretation is rather a description of a factual state of affairs than a metaphor. However, because "home" has a wider connotation than "house," it has a metaphorical meaning as well. At home, people can be expected to have a stronger sense of autonomy and control than elsewhere, they can be expected to be more comfortable, and they may have the protection and security of relatives.

In Doris Lessing's novel The Diary of a Good Neighbour, the main character, the ninety-plus-year-old Maudie Fowler, desperately tries to stay at home despite the fact that she is suffering from a serious disease (bowel cancer) [28]. Although she can hardly take care of herself, she does not want to give up her autonomy and to be dependent on "good neighbours" and other caregivers. She feels at home in her own house, although it is in a mess. For Janna, the young woman of the world, who feels much sympathy for Maudy and seeks to take care of her, "home" is a difficult word. Janna spends most of her life at the editorial office of the magazine where she is the editor-in-chief. She realizes that her bathroom is the place where she actually lives and where she feels at home. Doris Lessing's novel illustrates that human beings definitely long for home, although in many different ways.

Until the end of the nineteenth century, medical care was mostly provided at home. After a period of immense growth of hospital-based care, home care has revived in the last 30 years. For many people, going home is the ideal pathway to which all treatments of grave and lengthy illnesses in hospital eventually converge. While medical technology for many years forced patients to remain confined in the hospital in order for care to be delivered up to the moment of death, more recent advances now allow many patients who would previously have been confined to a medical institution to return home. Hospital-based home care has become an important aspect of modern palliative care. In most European countries several kinds of home care programs for terminally ill cancer patients have been set up.

Many people do not live in their own house, but in a home for the elderly, a nursing home, a psychiatric institution, a rehabilitation center, or an institution for mentally handicapped or chronically ill people. Care given to these people should focus on making them feel at home in a homelike "surrogate home" environment [26]. The architecture of such a surrogate home can contribute considerably to the well-being of its inhabitants. It is argued, for example, that architects of nursing homes for persons with Alzheimer's disease should take into account the needs of patients and their caregivers more carefully [29].

Footnote 6 continued

strive for the ideal of "Satyagraha," in which being at home with oneself, with others, with nature, and with God are intrinsically linked [27] . 
One of the surrogate homes is the hospice. Hospice care is inextricably linked with home care. The first modern hospices were in-patient units, often with an associated home care service for those who could still be cared for at home. In recent years, incurably ill patients have increasingly expressed a preference to die at home. This has prompted the creation of a wide range of home-based hospice services and home care services [30].

When patients have to be admitted to hospital, nursing home, or some other health care institution, caregivers should strive to send them back home as soon as possible. This is, however, not a hard and fast rule. There are many situations in which patients would be unsafe at home because sufficient care cannot be provided for them there, or where they actually do not wish to go home. This does not mean, however, that going home in this first interpretation is not an ideal for many of us.

\section{(2) One's own body}

Many people do not have a house of their own and some do not even have a surrogate home. However, even so-called homeless people do have homes. They appear to be inventive in creating alternative homes in tents and cardboard houses in parks, under bridges etc. But there is more. They often appear to have a special relationship with their own body. Their body is, so to speak, a territory that they do not easily give up. Their own body is their home. This observation leads to a second meaning of "feeling at home," that is, feeling comfortable in one's own body. Referring to Plato's metaphorical idea of the human body as a dungeon of the soul, this second interpretation can be summarized as the human body as a home for the soul.

From a phenomenological perspective, the body can be considered the place where, in an ideal situation, the person feels at home. Human beings are fixed in their bodies and their body is an aspect of themselves. However, we cannot identify completely with our bodies, nor can we detach ourselves completely from our bodies. According to Marcel we are our body and we have our body at the same time [31]. When someone touches my arm, I can say "you touched my arm" or "you touched me." Both articulations are correct.

Considered from the perspective of "having," the body is a home for us like the shell of a snail. Buytendijk describes the human body as "the first and last situation that a human being comes across in their life and to which they give meaning" [32, p. 302]. Martha Nussbaum writes: "We live all our lives in bodies of a certain sort [...] These bodies [...] are our homes, so to speak, opening certain options and denying others, giving us certain needs and possibilities for excellence ..." $[33$, p. 76]. As the "owner" of his body, the person should maintain his own house as well as possible and repair it where necessary, but physicians and other health care workers can also be seen as stewards of the patient's body. Since time immemorial bodily well-being has been considered a central goal of medicine.

Many patients who need palliative care show bodily deteriorations and a decay of bodily functions. They suffer from pain, nausea, shortness of breath, itching, etc., and lose control over their body. They may experience considerable difficulties in maintaining a sense of self once they have lost the bodily capability to do and act in 
an independent way, for example, in case of paralyses and incontinence of urine and feces [34]. The second interpretation of bringing the patient home implies the whole range of activities focused on pain relief and symptom control in order to provide the patient with the most comfortable possible "bodily home." It is beyond doubt, however, that in many cases this ideal cannot be achieved.

\section{(3) Psychosocial environment}

Compared to the second and fourth interpretation, this third one is less of a metaphor. A harmonious relationship with others is generally considered one of the key elements of feeling at home in a psychosocial sense. Crucial in this third interpretation of feeling at home is the experience of taking part in a surrounding of sharing one's life with fellow human beings. Psychological well-being and quality of life is the issue here.

Nowadays, it is widely agreed that the goal of palliative care is to treat patients with advanced incurable diseases in a way that optimizes the well-being and quality of life of patients and family members. ${ }^{7}$ It is recognized that besides being at home in one's own house and body, patients should also feel at home in a psychosocial environment. According to the WHO, palliative care integrates the psychological and spiritual aspects of patient care, offers a support system to help patients live as actively as possible until death, and helps the family cope during the patients illness and in their own bereavement. Palliative care uses a team approach to address the needs of patients and their families including bereavement counseling.

One of the implications of this third interpretation is that caregivers should pay attention to the patients' preferences, and their personal norms and values. The Latin word hospitium originally meant the warm feeling between host and guest, and was later extended to the place where this feeling was experienced. The primary purpose of a hospice was to be a resting place for travelers and pilgrims. A hospice therefore might be an excellent place-but of course not the only place-in which the psychosocial needs of incurably ill patients are met. Wherever the patients actually lives, in his own house or in a health care institution, he deserves a home in the sense of a warm psychosocial environment [36, 37].

Sometimes, the idea of going home can be taken literally. For many patients in a psychogeriatric institution, "home" appears to be a key word [38, 39]. People with dementia who live in a nursing home often say they have to go home because they think their children are coming home from school. They often search diligently for a safe home in the sense of spiritual familiarity and security. Listening to songs that they know from their childhood can enhance feeling at home.

\footnotetext{
7 The WHO defines palliative care as "an approach that improves the quality of life of patients and their families facing the problem associated with life-threatening illness, through the prevention and relief of suffering by means of early identification and impeccable assessment and treatment of pain and other problems, physical, psychosocial and spiritual" [35].
} 
(4) Spiritual dimension: origin of human existence

For about four decades, pastoral care for spiritual and existential beliefs of patients in a palliative phase has been of paramount importance. Cicely Saunders' so-called "total pain concept" explicitly recognizes the spiritual and existential dimension of pain along with the somatic, psychological and social aspects [40]. Spiritual and existential beliefs refer to the way people find meaning, purpose, and value in their lives. These meanings can be specifically religious, but even people who have no religious faith or are not members of an organized religion have belief systems that give their lives meaning and purpose. Spiritual and existential issues become especially urgent for people confronting death and the consequent questions about the purpose of their life. ${ }^{8}$

The fourth interpretation specifically relates to the fact that home is often associated with the place where one originates. Coming home is a journey back to one's roots, a journey in which the past (the roots) and the future (the journey) are interwoven. This interpretation is quite different from the three already mentioned, because it concerns a religious or metaphysical metaphor. It refers to the dying process, in particular to the religious conviction that human beings after death return to their place of origin. The end of an episode of palliative care is usually the patient's death, i.e., the end of one's existence in one's own house, body and psychosocial environment. Therefore, while dying means leaving home and going on a solitary journey to a "nowhere land," it also means coming home.

The conviction that human beings survive physical death has been very differently elaborated in the history of philosophy and religions, but in some form has persisted throughout Western civilization [42]. Monotheistic religions such as Judaism, Christianity and Islam have symbolized death as a journey, as one's return to the Creator. ${ }^{10}$ This conviction is connected to the idea of the human being as a homo viator. The life of human beings is like an odyssey that comes to an end when one finds one's way home. People from these three religions consider their dying as a coming home, as a reunion in the hereafter not only with their Creator, but also with relatives and loved ones who have died earlier [43].

This fourth interpretation of the goal of palliative care might support pleas to further develop an ars moriendi [44-46]. According to Cicely Saunders, the last stages of life should not be seen as defeat, but rather as "life's fulfillment" [47].

\footnotetext{
8 There is evidence that, although people with advanced dementia are existentially wobbly, many of them begin this final phase of their lives with a profound recovery of spirituality. Stephen Post tells the story of Peter, whose diagnosis of dementia was accompanied by something like a "spiritual conversion" [41]. Though dementia may seem to be an attack on the self, it brought Peter an unsought and unexpected discovery of self. The question posed by Post whether it is possible that people with dementia might be spiritually enriched, even as they dwell "within the depths of despair," definitely needs further research.

9 "Bringing the patient home" as a goal of palliative care does not (necessarily) imply, of course, actually bringing about or causing the patient's death.

${ }^{10}$ I have avoided the question whether the metaphor of coming home in this fourth interpretation also applies to non-Christian views of death and dying. One could think, for example, of the Platonic idea of the soul returning to its origin and of the mere shadow existence in earthly life. Further, the Buddhist notion of the "nirwana" (a permanent state of salvation) and also the idea of (physical) death as a going back to nature and its biological constituents might be relevant here.
} 
According to Kübler-Ross, all that we are and all that we have done culminates in our death. When we are dying, we get our final chance for growth. We need not wait until death before we can really live. If we see death as an "invisible, but friendly, companion of our life's journey," we can start this "real life" somewhat earlier. For Kübler-Ross death is "the key to the door of life" [48, p. 164].

It is not difficult to recognize in these ideas of Saunders and Kübler-Ross an echo of the Heideggerian idea that death is inextricably linked with human existence. Human existence is essentially characterized as "being-toward-death" [15]. As long as death has not yet occurred, human existence has not yet reached its end, since there is a "not yet" still to come. Death brings life to an end and completes man's existence as a dynamic whole.

\section{On the metaphor of coming home}

What are the potentials and limitations of metaphorically describing the goals of palliative care in terms of being or coming home?

First, the metaphor is an ideal one because "home" generally evokes positive feelings. One must be aware, however, that home also has a dark side. "Home is the girl's prison and the woman's workhouse," G.B. Shaw wrote [6, quotation on p. 209]. In the literature, one can find warnings against a one-sided view in which home is described in nostalgic and utopian terms such as a secure and peaceful place, the place where individuals and families can escape the pressure of the modern world and express their individuality and autonomy in private [20]. Nostalgic views ignore the existence of alternative experiences, for example, that home can be a place of negative values for those who are abused, and can signify a public place for those who, paradoxically, find privacy on the streets.

Second, the strength of the first, spatial, interpretation of coming home is that it is not difficult to assess whether or not that specific goal has been reached. The three other interpretations, however, are increasingly open to discussion. This has to do with the very broad notion of home. Svenaeus rightly remarks that "unhomelikenes" is a general aspect of human existence that is experienced in many situations and not exclusively in illness [14]. Coming home can be seen as the goal of human life as such, healthy or diseased: we all have a responsibility to support each other in coming home. This way of reasoning might be correct, but the strong point of the metaphor of coming home in relation to palliative care is that it emphasizes the humane and personal character of medicine and health care and the health caregiver's responsibility. Moreover, it is not relevant whether palliative care is considered a part of health care or a specialty on its own, or whether a safe coming home is supported by health care professionals (physicians, nurses, pastoral workers) or lay persons.

Third, a crucial question is whether the four interpretations of coming home presented here form a kind of hierarchy and whether one form of coming home is more important than another. From a Christian perspective, one could argue that it does not matter where and how one dies, assuming that one has a safe coming home in the fourth meaning. Yet the place where and the manner in which one dies clearly 
influence the quality of coming home. People increasingly wish to die at home and to make the dying process a meaningful experience for themselves and their relatives. The goal of the Foundation Dutch Hospice Movement, for example, is "to support already existing possibilities for terminally ill people to complete their life in their own environment" [49]. It is telling that the Dutch hospices are sometimes called "Almost-at-Home-Homes" ("Bijna Thuis Huizen"). This term can be understood as (1) a home that is more or less similar to one's own home, and as (2) an environment in which one is almost at home in the religious sense of the word.

Fourth, metaphorical thinking in terms of coming home can deepen our philosophical understanding of the goals of palliative care, but might also have some practical relevance. It can, for example, provide new ways of thinking about the role caregivers play in patients' lives. Caregivers can ask themselves: "What can I contribute to make the patient feel at home?" The metaphor of coming home refers to the idea of a good life and a good death which has always been considered the object of ethics. By taking care of a patient's safe coming home in the four interpretations of the term home presented here, the caregiver can help the patient to live and to complete a good life.

Fifth, the fourth interpretation I presented here is not meant as a blueprint for palliative care practice. One must be cautious of what in the literature has been called "the good death model" or "the ideology of the good death" [50-52]. Patients need to be allowed to define for themselves what constitutes a good life and death for them. This does not mean, however, that we are not aware of and aim at an ideal way of living and dying. Speaking in terms of "home" and "coming home" can function as a heuristic tool, which might open new ways of interpreting the goals of palliative care.

Finally, teaching metaphorically thinking as part of the program of the medical humanities can contribute to the development of a moral attitude in a caring relationship [53]. Health care practitioners are daily confronted with the complex interplay of the generality of a specific disease and the patient's unique, individual and emotional response to it. Narrative arts forms such as novels and films can help us understand that interplay. Reading about and reflecting upon the idea of coming home might inspire them to get a better understanding of the individual patient's narrative and of the goals of palliative care. Doris Lessing's The Diary of a Good Neighbour, amongst many other novels and movies about home, may serve this goal.

\section{Conclusion}

The notion of home is well known from our everyday experience, plays a crucial role in all kinds of narratives about human life, but is hardly ever systematically dealt with in the philosophy of medicine and health care. By metaphorically describing the goal of palliative care as "the patient's coming home," I have attempted to contribute to a medical humanities approach to medicine. Thinking in terms of coming home implies a normative point of view. It represents central human values and refers not only to the medical-technical and care aspects of health 
care, but also to the moral context. The fact that caregivers know about home from their everyday lives can inspire them to provide the patient with such a home. This can imply getting the patient back to his own home, but can also prompt an attempt to create a new home for him.

Acknowledgement I thank Fredrik Svenaeus, Rolf Ahlzen, Paul van Tongeren and Jacques de Visscher for their comments on an earlier draft of this paper. I am also grateful to two anonymous reviewers for their helpful remarks.

Open Access This article is distributed under the terms of the Creative Commons Attribution Noncommercial License which permits any noncommercial use, distribution, and reproduction in any medium, provided the original author(s) and source are credited.

\section{References}

1. Lessing, Doris. 1968. Going home. Frogmore, St Albans: Panther books.

2. Bachelard, Gaston. 1964. The poetics of space. Boston: Beacon Press.

3. Cassell, Eric. 1991. The nature of suffering and the goals of medicine. New York/Oxford: Oxford University Press.

4. Randall, Fiona, and Robin S. Downie. 2006. The philosophy of palliative care: Critique and reconstruction. Oxford: Oxford University Press.

5. Baldursson, Stefan. 2002. The nature of at-homeness. http://www.phenomenologyonline.com/ articles/baldursson.html. Accessed 16 September 2009.

6. Moore, Jeanne. 2000. Placing home in context. Journal of Environmental Psychology 20: 207-217.

7. Doyle, Kenneth O. 1992. The symbolic meaning of house and home. American Behavioral Scientist 35: 790-802.

8. Lakoff, George, and Mark Johnson. 1980. Metaphors we live by. Chicago and London: The University of Chicago Press.

9. Ricoeur, Paul. 1975. La métaphore vive. Paris: Éditions du Seuil.

10. Krasner, James. 2006. Accumulated lives: Metaphor, materiality, and the homes of the elderly. Literature and Medicine 24: 209-230.

11. Utsumi, A. 2007. Interpretive diversity explains metaphor-simile distinction. Metaphor and Symbol 22: 291-312.

12. Svenaeus, Fredrik. 2000. Das unheimliche-towards a phenomenology of illness. Medicine, Health Care and Philosophy 3: 3-16.

13. Svenaeus, Fredrik. 2001. The hermeneutics of medicine and the phenomenology of health. Dordrecht: Kluwer Academic Publishers.

14. Svenaeus, Fredrik. 2001. The phenomenology of health and illness. In Handbook of phenomenology and medicine, ed. S. Kay Toombs, 87-108. Dordrecht: Kluwer Academic Publishers.

15. Heidegger, Martin. 1927. Sein und Zeit. Tübingen: Niemeyer.

16. Heidegger, Martin. 1954. Bauen wohnen denken. In Vorträge und aufsätze. Pfüllingen: Neske.

17. Bollnow, Otto. 1955. Neue geborgenheit. Stuttgart: Kohlhammer.

18. Emmanuel, Levinas. 1961. Totalité et infini: essai sur l'exteriorité. The Hague: Nijhoff.

19. Perkins, Harvey, David Thorns, Ann Winstanley, and Bronwyn Newton. 2002. The study of 'home' from a social scientific perspective: An annotated bibliography, 2nd ed. New Zealand: Canterbury.

20. Lawrence, Roderick C. 1987. What makes a house a home? Environment and Behavior 19: 154-168.

21. Douglas, Mary. 1991. The idea of a home: A kind of space. Social Research 58: 287-307.

22. Eliot, T.S. 1971. East Coker, Four quartets in The complete poems and plays. NY: Harcourt Brace Jovanovich.

23. Winnicott, Donald W. 1986. Home is where we start from. Essays by a psychoanalyst. Harmondsworth: Penguin Books.

24. Bollnow, Otto. 1961. Lived-space. Philosophy Today 5: 31-39. 
25. Winning, Anne. 2002. Homesickness. http://www.phenomenologyonline.com/articles/winning.html. Accessed 16 September 2009.

26. Kontos, Pia C. 1998. Resisting institutionalization: Constructing old age and negotiating home. Journal of Aging Studies 12: 167-184.

27. Pandikattu, Kuruvila. 2007. Being at home in the universe. In Catholic contributions to bioethics, ed. Baiju Julian and Hormis Mynatty, 436-454. Bangalore: Asian Trading Corporation.

28. Lessing, Doris. 1983. The diary of a good neighbour. New York: Knopf.

29. Bermann, Karen. 2003. Love and space in the nursing home. Theoretical Medicine 24: 511-523.

30. McLaughlin, D., K. Sullivan, and F. Hasson. 2007. Hospice at home service. Supportive Care in Cancer 15: 163-170.

31. Marcel, Gabriel. 1935. L'être et avoir. Paris: Gallimard.

32. Buytendijk, F.J.J. 1968. Woman. A contemporary view. New York: Newman Press and Association Press.

33. Nussbaum, Martha. 1995. Human capabilities, female human beings. In Women, culture, and development: A study of human capabilities, ed. Martha C. Nussbaum, and Jonathan Glover, 61-104. New York: Oxford University Press.

34. Lawton, Julia. 2000. The dying process. Patients' experiences of palliative Care. London and New York: Routledge.

35. WHO. 2009. Definition of palliative care. http://www.who.int/cancer/palliative/definition/en/ (accessed 5 June 2009).

36. Carlson, Melissa, Sean Morrison, Theodore Holford, and Elizabeth Bradley. 2007. Hospice care: What services do patients and their families receive? Health Services Research 42: 1672-1690.

37. Kelly, Brian, Francis Varghese, Paul Burnett, Jane Turner, Marguerite Robertson, Patricia Kelly, Geoffrey Mitchell, and Pat Treston. 2008. General practitioners' experiences of the psychosocial aspects in the care of a dying patient. Palliative and Supportive Care 6: 125-131.

38. Meijer, Marika. 1992. 'Thuis' is het sleutelwoord. De Bazuin 18: 24-26.

39. Meijer, Marika.1993. Alleen God weet nog waar ik woon. Pastorale zorg in het verpleeghuis. Speling: 62-66.

40. Saunders, Cicely. 1967. The management of terminal illness. London: Hospital Medicine Publications.

41. Post, Steven G. 2004. Alzheimer's \& grace. First Things. The Journal of Religion, Culture, and Public Life 142: 12-14.

42. Momeyer, R.W. 2004. Death. Western philosophical thought. In Encyclopedia of bioethics, vol. 2, 3rd ed, ed. Steven G. Post, 558-571. New York: MacMillan Reference USA.

43. Douma, J. 1998. Death in Christianity. In Death. Medical, spiritual and social care of the dying, ed. A.B.M.F. Karim, H.M. Kuitert, D.W.W. Newling, and V. Wortman, 143-156. Amsterdam: VU University Press.

44. Vogt, C.P. 2004. Patience, compassion, hope, and the Christian art of dying well. Lanham: Rowman \& Littlefield Publishers, Inc.

45. Woods, Simon. 2007. Death's dominion. Ethics at the end of life. Maidenhead: Open University Press/McGraw-Hill.

46. Leget, Carlo. 2007. Retrieving the ars moriendi tradition. Medicine, Health Care and Philosophy 10: 313-319.

47. Saunders, Cicely. 1965. The last stages of life. American Journal of Nursing 65: 70-75.

48. Kübler-Ross, Elisabeth. 1975. Death. The final stage of growth. Englewoods Cliff: Prentice-Hall.

49. Sluis, Pieter. 1997. Stichting Nederlandse Hospice Beweging 10 jaar oud. Medisch Contact 52: 171-172.

50. Dekkers, Wim, Lars Sandman, and Pat Webb. 2002. Good death or good life as a goal of palliative care. In The ethics of palliative care. European perspectives, ed. Henk ten Have and David Clark, 106-125. Buckingham/Philadelphia: Open University Press.

51. Sandman, Lars. 2001. A Good death. On the value of death and dying. Göteborg: Acta Universitatis Gothoburgensis.

52. Clark, David. 2002. Between hope and acceptance: The medicalisation of dying. British Medical Journal 324: 905-907.

53. Olthuis, Gert, and Wim Dekkers. 2003. Medical education, palliative care and moral attitude: Some objectives and future perspectives. Medical Education 37: 928-933. 